\title{
ABCC5 Gene
}

National Cancer Institute

\section{Source}

National Cancer Institute. ABCC5 Gene. NCI Thesaurus. Code C103949.

This gene plays a role in the transport of org anic anions and nucleotides. 